FACTA UNIVERSITATIS

Series: Law and Politics Vol. 17, N 3, 2019, pp. 197-208

https://doi.org/10.22190/FULP1903197G

Original Scientific Paper

\title{
RULE OF LAW AND DEMOCRATIC CONSOLIDATION IN SERBIA *
}

\author{
UDC 321.7:340.131(497.11)
}

\author{
Nataša Golubović ${ }^{1}$, Srđan Golubović \\ ${ }^{1}$ Faculty of Economics, University of Niš, Serbia \\ ${ }^{2}$ Faculty of Law, University of Niš, Serbia
}

\begin{abstract}
Renowned international organizations classify Serbia as a democracy. However, they usually assess the state of democracy on the basis of the narrow theoretical concept of electoral democracy, which easily creates a fallacy that the free elections represent not only a necessary but sufficient condition for democracy. The concept of liberal consolidated democracy, in addition to procedural aspects, implies stricter normative and analytical criteria, such as the rule of law and the mechanisms of vertical and horizontal accountability, which constitute institutional guarantees for the application of fundamental democratic principles. In the absence of these mechanisms, electoral democracies become defective. According to relevant research, Serbia is classified as a semi-consolidated (defective or flawed) democracy. Irregularities in election procedures, as well as the violation of elements that guarantee respect for democratic norms and institutions in recent years indicate a certain democratic "regression". Bearing this in mind, the paper examines the extent to which the rule of law represents support to the consolidation of democracy in Serbia and points out to the potential causes of the observed deficiencies in this area, which aggravate the consolidation of democracy.
\end{abstract}

Key words: democracy, consolidation, rule of law, Serbia

\section{INTRODUCTION}

After more than two decades of political and economic reforms, Serbia is still in a state of prolonged democratic transition, with uncertain prospects for the full consolidation of democratic institutions. According to relevant empirical research, Serbia is classified as a

Received April 24 $4^{\text {th }}, 2019 /$ Accepted June $5^{\text {th }}, 2019$

Corresponding author: Srđan Golubović, LL.D. Faculty of Law, University of Niš, Trg Kralja Aleksandra 11, 18000 Niš, Serbia; E-mail: golub@prafak.ni.ac.rs

* The article is the result of reserach within the project Sustainability of the identity of Serbs and ethnic minorities in border municipalities in eastern and southern Serbia (179013), conducted at the Faculty of Mechanical Engineering, University of Niš, and funded by the Ministry of Science and Technology of the Republic of Serbia 
semi-consolidated (defective or flawed) democracy. Irregularities in election procedures, as well as the violation of elements that guarantee respect for democratic norms and institutions in recent years indicate a certain democratic regression. There are no guarantees that reform will necessarily lead to democratic consolidation. Since democratic consolidation has not been achieved yet, research on progress in the area of democratic consolidation and the problems that arise in this process is very important, especially having in mind that the way in which consolidation is achieved determines the performance of the democratic regime after consolidation. It is important to understand the challenges that these regimes face and what makes democratic structures more resilient. Serbia is considered a defective democracy, with most pronounced weaknesses in the areas of rule of law, political and social integration and institutional stability. Weak rule of law, combined with weak horizontal accountability, could undermine the entire democratic system. Starting from this, the paper examines the extent to which the rule of law is a support to the consolidation of democracy in Serbia and points to the potential causes of deficiencies in this area, which impair the essential transition to democracy.

\section{DEMOCRATIC CONSOLIDATION}

The process of consolidation and the factors that are crucial for the consolidation of democracy have been the subject of numerous theoretical and empirical researches (Linz \& Stepan, 1996; Diamond, 1999; O'Donnell, 1996). In defining democratic consolidation, some authors start from the minimum of necessary conditions (Schumpeter, 1942; Przeworski, 1991), while others consider that democracy is not sustainable without the fulfillment of additional requirements that ensure the constitutional equality of all citizens (Huntington, 1991; Linz \& Stepan, 1996). Within the minimalist definitions, the most commonly quoted author is Przeworski, who defines democracy as simply "a system in which parties lose elections". A minimalistic understanding of democracy presupposes the existence of an opposition that has some prospects to win elections, through the contesting process. Democracy is consolidated when, in the prevailing political and economic conditions, the existing system of institutions has no alternative, when no one tries to achieve their interests outside democratic institutions, and when those who are losing election are trying again within the same institutional framework, within which they have just lost (Przeworski, 1991: 26). The emphasis is on the actors, their attitudes and behavior; they have to accept the legitimacy of institutions, even when they consider them unsuitable. Critics of the concept of electoral democracy point out that this approach is incomplete and has limited analytical usefulness. Merkel (Merkel, 2004; 2008) points out that, although free democratic elections constitute the basis of democracy, it is necessary to take into account some additional elements concerning the procedures and goals of democratic elections that differentiate formal and substantive democracy. The concept of electoral democracy reduces democracy to the proper conduct of democratic elections, but it does not include necessary institutional guarantees providing that elected representatives rule in accordance with the basic constitutional principles of democracy. The definition of democracy, based on electoral democracy, free elections and some basic corpus of human rights allows certain political regimes to be qualified as democratic, even though elections in such regimes are defective and certain groups are socially and politically excluded. The disadvantage is that many factors that are important from the aspect of democracy are omitted. The assessment of the consolidation of democracy 
cannot be grounded on the minimum requirements for the existence of democracy, but on the criteria that make democracy stable. This is why theoretical and empirical researches are increasingly based on the definitions that apply a broader set of criteria and emphasize the essence of democracy, both horizontal and vertical accountability.

Probably the most frequently cited concept of democratic consolidation is the one developed by Linz \& Stepan (1996), which takes into account different levels of democratic consolidation. The first level refers to the consolidation of behavior; the democratic regime is consolidated when there are no important actors in a society trying to achieve their goals by return to the undemocratic regime, through violence or foreign intervention. The second level implies consolidation of attitudes; democracy is considered to be consolidated when the majority in the society considers democratic institutions and procedures appropriate for the management of the society, and when the support to anti-system alternatives is negligible. The third is a constitutional dimension (conflict resolution through democratic procedures and rules). Consolidation takes place in five areas: civil society, political society, rule of law, state apparatus, and economic sphere. In each of these areas, it is necessary to fulfill certain conditions in order for democracy to be considered consolidated. This concept is more comprehensive than the previous ones since it enables the analysis of system consolidation at three different levels, including civil culture (behavioral dimension).

Merkel's (2008) concept of democratic consolidation is probably the most comprehensive. Merkel has developed a four-level model of consolidation, with analytical sequencing of consolidation levels and an analysis of their interdependence. If all four levels are consolidated, one can say that democracy is consolidated and resilient to crises. Institutional consolidation refers to the consolidation of state bodies and political institutions, such as government, parliament, judiciary and the electoral system (with special emphasis on the rule of law and separation of powers). Institutional consolidation determines the next level, which is representative consolidation. This level refers to the main actors of representative democracy - political parties and interest groups. The degree of consolidation of the first and second levels, as well as their configuration, influences the incentives of powerful informal actors (church, military, entrepreneurs, etc.) to exercise their interests outside democratic institutions (consolidation of behavior). If the first three levels are consolidated to a satisfactory degree, it gives impetus to the development of a civil society that supports democracy, thus stabilizing the socio-political foundation of democracy (the consolidation of civic culture). In this context, Merkel distinguishes general support and specific support (related to specific political decisions) as a criterion for the consolidation of civic culture. Consolidation of civic culture is a process that requires time. Consolidated, crisis-resistant democracy is present only when all four levels are consolidated.

\section{THE RULE OF LAW AND DEMOCRATIC CONSOLIDATION}

Research has shown that hybrid political regimes, based on more or less competitive choices, are more likely to transform into other regimes, whether consolidated democracy or some form of autocratic regime (Hadenius \& Teorell, 2007; Howard \& Roessler, 2006; Roessler \& Howard, 2009). A certain number of so-called defective democracies remain long in the gray zone of mixed regimes that neither further consolidate democracy nor return to the authoritarian regime. Such regimes can develop stable relationships with the environment, which become accepted by the elite and the public as an adequate solution to the numerous problems present in post-authoritarian societies (Merkel, 2004). 
It is often emphasized that the rule of law is essential for democracy. Sagay claims that "there can be no democracy without the rule of law" (1996: 13). Violating the rule of law and horizontal accountability can destabilize other parts of the democratic regime and easily lead to the return to authoritarianism (Merkel, 2004). The rule of law is such a system in which laws are well known, clear, accessible to all and applied equally; judges are impartial and independent of any influence; key institutions of the legal system, including courts, regulatory agencies, prosecutors and the police are fair, competent and efficient; the government and its officials respect the laws; laws are made according to transparent, stable, clear and general rules and procedures; and the laws themselves are known, clear and relatively stable.

The essence of the rule of law lies in respect for and protection of fundamental human rights and freedoms. Effective protection of these rights implies an independent judiciary, as a corrective of legislative and executive power. The limitations of the legislative and the executive power prevent individuals and groups from being oppressed by the majority. The principle of the rule of law implies a restriction in the exercise of state power and implies that the state must comply with the rules and act in accordance with clearly defined prerogatives (Elster, 1988).

A fair and efficient administration of justice, including the organization and functioning of the country's justice system, is a prerequisite for the rule of law (Prica, 2018: 140). The content of the law loses importance if the institutions established for the interpretation and implementation of these laws are ineffective, arbitrary or corrupt. For these reasons, the reform of the judiciary and institutions (including the appointment and promotion of judges, education and training of judicial staff, transparency in decision making and the availability of court services and officials) are the preconditions for building a fair, open and efficient legal system.

The rule of law represents the horizontal backbone of the institutional minimum of democratic elections and democratic participation. According to O'Donnell (1998), horizontal accountability implies that elected representatives, entrusted with the exercise of public power, are under the constant control of independent institutions. Institutionalizing the horizontal accountability allows control of the basic democratic structure. Institutalizing the vertical accountability ensures periodical control of the government through elections and public opinion. Protection of civil rights prevents the violation of individual freedoms by the state. Division of power into legislative, executive and judicial power, where each of the aforementioned branches of government represents a counterweight to others, prevents the abuse of power. Horizontal accountability ensures that responsibility and responsiveness of the public authorities are ensured not only periodically, at the time of the election, but also continuously, through the system of checks and balances between different branches of government (Beetham \& Boyle, 1995: 66).

It quickly became clear that comprehensive political and economic reforms in transition countries will be difficult to implement and maintain with an inadequate or outdated legal system, deprived of functional institutions that would ensure application of existing rules and the resolution of disputes. Reforms of the legal framework in transition countries have two key elements. The first is reconsideration of formal rules, including the constitution, laws, regulations, and so on. This segment of reforms should ensure that the content of the rules meets the needs of the society and that they are the result of some kind of participation of those to whom these rules apply. The second is the effective implementation of formal rules. The rule of law rule has become one of the main priorities in the process of enlargement of the European Union to the Western Balkans/European integration of the Western Balkan 
countries. At the beginning of this process, European Union requested from candidate countries to fulfill formal legal criteria, ignoring the inherited specificities of the legal systems of post-socialist countries. However, it turned out that, beside formal rules, informal rules are also important for the strengthening of the rule of law. This tension between formal and informal rules has remained an important feature of developments in the sphere of the rule of law in transition countries. Bearing in mind the poor state of the rule of law, the EU has extended over time the standard Copenhagen criteria to include the rule of law promotion strategy, which emphasizes the implementation and irreversibility of reforms.

\section{CONSOlidation OF DEMOCRACY IN SERBia}

According to renowned international organizations who regularly publish democratization indices, Serbia has made significant progress in the development of democratic institutions during the last two decades. Serbia is ranked as a democratic country, that is, a country that guarantees its citizens basic political rights and civil liberties (Table 1). Such estimates are based on the concept of a democratic minimum, which is almost exclusively related to electoral democracy. This implies that an institutional minimum has been achieved in Serbia in terms of the general suffrage and implementation of free and fair elections. Although detailed analysis points to deficiencies within the electoral process, Serbia can be classified into a type of electoral democracy.

According to theories of democratic transformation, the process that begins with the transition from autocratic to democratic regime has several potential outcomes, of which consolidated democracy is the best possible scenario. However, in a large number of cases, as in the case of Serbia, the institutionalization of democracy is not necessarily followed by the process of consolidating democratic institutions. Some new democracies could easily remain captured in a state of incomplete consolidation for a long time. Such democracies are characterized by anomalies in the functioning of certain elements of the democratic system, which makes them flawed or defective democracies. The data in Table 1 indicate that, after more than two decades of democratic transformation, Serbia today belongs to the category of defective (semi-consolidated) democracies. In the latest Freedom House report, Serbia is rated as a partially free country, which indicates deterioration as compared to the previous year when we were in the group of free countries. The causes of this fall, according to the Freedom House report, are electoral irregularity and distrust in the election process, pressure on certain media and journalists, as well as concentration of power in the hands of the president of the republic (violation of the principle of separation of powers).

Table 1

\begin{tabular}{llll}
\hline Index & Score & Status & Status \\
\hline Bertelsman Transformation Index & $7,70 / 10$ & Democracy & Defective democracy (6-8) \\
FH Nations in Transit & $3,97 / 7^{*}$ & Democracy & $\begin{array}{l}\text { Semi-consolidated } \\
\text { democracy }(3-3,99)\end{array}$ \\
FH Freedom in the World & $67 / 100$ & Democracy & Partly free \\
Economist Intelligence Unit & $6,41 / 10$ & Democracy & Flawed democracy (6-8) \\
\hline
\end{tabular}

${ }^{*}$ Score ranges from 1 to 7 , where 1 denotes the highest and 7 denotes the lowest level of democratization. Source: Bertelsman Foundation 2018, Freedom House 2018, Freedom House 2019, Economist Intelligence Unit 2018. 
Recent research on hybrid regimes and defective democracies has shown that a weak rule of law, combined with weak horizontal accountability, could undermine the entire democratic system (Merkel et al., 2003). Serbia is considered to be a defective democracy, with most pronounced shortcomings in the areas of rule of law, political and social integration and institutional stability. Defective democracies represent a mixture of multiparty systems, competitive elections parliaments and other elements usually associated with liberal democracies and mechanisms and techniques of the authoritarian regimes. These practices lead to the further de-institutionalisation of fragile democratic structures and to their ongoing deterioration. Weak rule of law and a barely functioning system of horizontal checks and balances undermine other parts of the democratic regime, and could ultimately call into question the meaningfulness of democratic elections.

\section{The Rule of LaW as a Determinant of Democratic Consolidation in SERBia}

The Bertelsman Transformation Index (BTI) ranks countries according to the quality of democracy and the market economy. It aggregates the results of political and economic transformation into two indices: The Status Index and The Governance Index. The Status Index, with its two analytical dimensions - political and economic transformation - shows where each of the 129 countries stands on the path to democracy, based on the rule of law and the social market economy. The results achieved in the field of political transformation are assessed on the basis of five indicators, among which is the rule of law. The rule of law indicator has four components: separation of powers, independent judiciary, prosecution for office abuse, and protection of basic civil rights. In addition to this indicator, additional insight into the level of rule of law can be obtained on the basis of the sub-indicator Protection of private property, within the framework of economic transformation. Within the political transformation, the weakest results in 2018 were achieved in the area of the rule of law (6.8). Within the economic transformation, Protection of private property was estimated at 7.5 (the lowest rating is 1 and the highest is 10) (Bertelsman Foundation, 2019).

A constant problem with the separation of powers in Serbia is the dominance of the executive over the judicial and the legislative powers. Although the power of the state is formally limited by law, this principle is violated in practice, in particular by passing laws under urgent procedures and violations of the independence of autonomous bodies, such as the Ombudsman. The Bertelsman Index estimates the separation of powers in Serbia as unsatisfactory (7/10) (Ibid). (Bertelsman Foundation, 2019). The judiciary is characterized by inefficiency and susceptibility to political influence. It is noted that there were no significant results in terms of increasing the judicial independence, which is one of the key problems and reform challenges for Serbia. Corruption is a significant weakness of the judiciary. Anti-corruption policy is not consistent because there are few sentences for official misconduct, and the activities and measures anticipated by the anti-corruption strategy and the action plan have not been fully implemented. Although the Constitution guarantees the rights and freedoms of citizens, in recent years there has been a significant limitation of the freedom of the media and freedom of expression in Serbia.

Nations in Transit (Freedom House). The Nations in Transit study, as part of the Democracy Score, assesses the degree of Judicial framework and independence as a key guarantor of civil liberties. The data for 2018 indicate that, despite the reforms carried out in this area, the failure to establish an independent judiciary, along with its inefficiency, is the 
greatest shortcoming of institutions in Serbia. Despite the government's declarative desire to improve the rule of law and the efficiency of the judicial system, partly under EU pressure, the quality of the judicial framework and the judicial independence in Serbia are considered unsatisfactory (4.5/7). Numerous problems of the Serbian judiciary are mentioned, such as exposure to political influences, financial dependence from the executive power, and the spread of corruption within the judicial system. A number of irregularities and delays in the process of election of judges were noted. This is the reason why estimates regarding the independence of the judiciary and the rule of law have been very low in the past few years (Freedom House, 2018).

An integral part of the Heritage Foundation's Index of Economic Freedom (economic freedom is estimated by using a scale from 0 to 100 , where the higher value of the indicator reflects a higher level of economic freedom) is a set of indicators of the rule of law (property rights, government integrity and efficiency of the judiciary), where Serbia is poorly rated. In the field of property rights, Serbia had an estimate of 50.1; the integrity of the government was 37.2, and the independence of the judiciary was 44.8. In addition, in the sphere of judicial independence, there was a decrease of 3.4 points as compared to the previous year. The Heritage Foundation's Report indicates that Serbian citizens and foreign investors are guaranteed property rights, but the implementation of these rights is slow. Independence of the judiciary is endangered by political influence, and corruption remains a major problem, with anti-corruption regulations not being applied effectively. The key areas in which reforms need to be deepened are: modernization of tax administration, reduction of corruption, and strengthening of the judicial system (Heritage Foundation, 2019).

Freedom in the World (Freedom House) is a global annual study of political rights and civil liberties. Starting from the fact that formal guarantees of citizens' rights and freedoms are not sufficient, this study, although evaluating both elements, places greater emphasis on the practical exercise of these rights than on the laws and regulations that regulate them. The Civil Liberties Index includes assessments of the freedom of expression and belief, association and organization rights, the rule of law, and the personal autonomy and individual rights. In the area of the rule of law, there was deterioration as compared to the previous year (from 10/16 to 9/16). According to the report, the state of civil liberties in Serbia can be considered satisfactory. However, a more detailed assessment of citizens' rights and freedoms suggests that Serbian citizens face difficulties in exercising formal rights. For example, ownership rights are guaranteed, but their protection is hampered by the inefficiency of the judicial system. Citizens freely decide to start their own business, but bureaucratic obstacles make this process more difficult. There is gender equality in Serbia, but women are faced with discrimination in the labor market. A significant problem in the sphere of the rule of law is political influence on the appointment of judges and judicial decisions, which threatens the independence of the judiciary. In the media, politicians regularly comment on court decisions, ongoing court proceedings and investigations. In the past period, political influence on the work of the police and the prosecution has been evident. For these reasons, the degree of independence of the judiciary was assessed as unsatisfactory (2/4) (Freedom House 2019).

Economic Freedom (Fraser Institute) measures the degree of economic freedom in five key areas. One of these areas is the Legal System and Property Rights. According to the Fraser Institute, in 2016 Serbia ranked 84th out of 162 countries, with an index of 6.85 (where 1 means the smallest and 10 the largest economic freedom). The lowest results were in the subindicator of the Legal System and Property Rights, where Serbia obtained 
unsatisfactory ratings in those segments that are crucial for the rule of law: judicial independence 3.05 , impartial courts 2.73 , protection of property rights 3.93 and legal enforcement of contracts 3.20 (Fraser Institute, 2016).

The Quality of governance (and the rule of law) within the Worldwide Governance Indicators is measured on the basis of several elements. Some of them are related to the independence of the judiciary, the fairness of court procedures, the speed of procedures, judicial responsibility and trust in the judiciary, as well as the implementation of the contract. Others refer to the degree of crime and the efficiency of law enforcement. Estimates for the rule of law range from -2.5 (weak governance effect) to 2.5 (strong governance effect). In the case of Serbia, there has been a continuous deterioration in the rule of law over the past ten years. The value of this indicator was 0.47 in 2007, 0.36 in 2012, and 0.19 in 2017 (World Bank, 2017).

According the subindicator of the Rule of law, within the International Property Rights Index (Property Right Alliance, 2018), Serbia scored 4,769, which places it 69th in the world and 16th in the region in 2018. According to the judicial independence, however, Serbia received a score of 3.046, ranking 108th in the world and 20th in the region. Investors have no problems with the registration of property (where Serbia is 54th in the world and 18th in the region, with a score of 9,291), but there are issues concerning the protection of property, where Serbia is ranked 112th in the world and 20th in the region (score 3.926). In the sphere of intellectual property protection, Serbia is 107th in the world and 21st in the region.

The Rule of Law Index of The World Justice Project probably represents the most comprehensive set of data of that kind in the world, which primarily relies on primary data in measuring the commitment of countries to the rule of law from the perspective of citizens and their experience. This index provides the basis for identifying strengths and weaknesses in the sphere of the rule of law and, on this basis, the formulation of measures that will contribute to the strengthening of the rule of law.

The Rule of Law Index of the World Justice Project - WJP (2019) measures the degree of rule of law based on the experiences and perceptions of citizens and legal professionals in countries around the world. Countries are assessed and ranked on the basis of eight factors: constraints on government powers, absence of corruption, open government, fundamental rights, order and security, regulatory enforcement, civil and criminal justice. The aforesaid indicators are based on two main principles concerning the relationship between the state and the governed. The first principle pertains to whether the law imposes limits on the exercise of powers by the state and its representatives, as well as individuals and private enterprises (factors 1, 2, 3 and 4 within the index). The second principle relates to whether a state limits the actions of members of society, fulfills its basic duties towards the population (serving the public interest), whether citizens are protected from violence, and whether all members of society have access to justice - dispute settlement and grievance mechanisms (factors 5, 6, 7 and 8 within the index). The index value ranges from 0 to 1 , where 1 denotes the highest degree of respect for the principle of justice, and 0 is the smallest. Serbia is ranked 78th out of 126 ranked countries, with a rule of law index of 0.5 . For comparison, on the list of all ranked countries, Slovenia is in the 26th place, Croatia is 42nd, Bosnia and Herzegovina is 60th, Macedonia is 56th and Albania is 71st. Among the Western Balkan countries, Serbia takes the last place (World Justice Project, 2019).

The first group of indicators refers to the Accountability of the government. Within the Rule of law index, it is accessed on the basis of two factors: constraints on government powers and the absence of corruption. The first factor, constraints on government powers, 
measures the extent to which the government respects the law. It includes mechanisms (both constitutional and institutional) that limit the power of government and its representatives, and make them accountable within the framework of the law. This factor also includes non-governmental mechanisms of government control, such as the free and independent press. Separation of powers is very important since it ensures that no branch of government has unlimited power. Serbia in this area received a score 0.40 , experiencing a continuous deterioration since 2012, when the value of this indicator was 0.48 (World Justice Project, 2012; 2019). The weakest link is the sanction for official misconduct, where Serbia received an exceptionally low score of 0.27 . Serbia is not well placed regarding the legal limitations of arbitrary power (0.42). The judiciary is responsible for the bad score in this area because of its inability to oppose the executive power (0.35). Non-governmental mechanisms of government control are marked as relatively weak. The second factor is the Absence of corruption. The degree of corruption shows the extent to which state officials are abusing their position for private gain. Different forms of corruption have been taken into account, examined in the sphere of legislative, executive and judicial power. Legislature is rated as the most corrupted $(0.26)$, followed by the judiciary $(0.49)$ and the executive authorities (0.46). The least corrupted were the police and the army $(0.54)$.

The second group of indicators refers to Security and Fundamental Rights and is estimated on the basis of two factors: order and security and fundamental rights. Order and security shows the extent to which the state provides security of individuals and property. Citizens' security is one of the basic aspects of the rule of law and the fundamental function of the state. Violence not only inflicts harm on society but also prevents achievement of other goals, such as achieving freedom and access to justice. This factor includes three dimensions: absence of crime, absence of political violence (terrorism, armed conflicts and political unrest), and violence as a way of resolving disputes. The fourth factor (Fundamental Rights) assesses the degree of protection of basic human rights. It includes: equal treatment of all citizens and absence of discrimination; right to life and security; freedom of expression and beliefs; freedom of association, including the right to collective bargaining; prohibition of forced and child labor; right to privacy. Among the eight factors covered by the Rule of the law index, Serbia scored above 0.5 only in the area of Order and Security (0.77) and Fundamental Rights (0.56), mostly due to freedom of religion (0.70), freedom of association (0.59), absence of discrimination (0.62) and the absence of civil conflicts (1.0). In the area of Order and Security there was an improvement, since the value of this factor increased from 0.75 to 0.78 , but in the area of basic rights there was deterioration from 0.61 to 0.56 as compared to 2012 (World Justice Project, 2012; 2019).

The third group of indicators is the Openness of state institutions and the Efficiency of the regulatory framework. These indicators show the extent to which the processes through which the laws are passed and applied are accessible, fair and efficient. It concerns access, participation and cooperation between the state and citizens, and it plays a key role in fostering accountability. Citizens' access to information of public importance is essential for ensuring the accountability of the authorities. When it comes to the Open government, there was some deterioration compared to 2016, but the value of this indicator is slightly higher than in 2012. In the area of the right to information, Serbia received a score of 0.48 , while the score for the attainability of laws and government documents was 0.52. Direct involvement of citizens, as well as civil society organizations, from the point of view of transparency and accountability of the authorities, is still in its infancy in Serbia. A more transparent and inclusive decision-making process contributes to better public policies. 
Cooperation with the civil society is necessary, both through civil society organizations and through individual activities (e.g. through complaint mechanisms). In this context, citizens' participation (0.47) and citizens' participation through complaint mechanisms (0.41) are unsatisfactory. Regulatory enforcement indicates the fairness and effectiveness of state regulation. An important feature of the rule of law is that the rules are respected and effectively enforced, without any abuse by state officials. In this area, Serbia received a score of 0.47 . The efficiency of the regulatory framework is relatively low (0.45), which is due to the fact that the rules are not implemented efficiently, as there are many undue delays in the application of the rules (0.40), as well as the improper influence (0.47) (World Justice Project, 2019).

The fourth group of indicators, The accessibility and affordability of justice, is monitored through the following factors: civil and criminal justice. Civil justice shows the extent to which citizens can resolve their disputes through formal institutions in a peaceful and effective manner, in accordance with commonly accepted social norms. Effective civil justice implies that the system is available and accessible, without discrimination and corruption, and without the improper influence of public officials. It is also necessary that court proceedings are conducted in a timely manner, without undue delays. Finally, recognizing the value of alternative dispute resolution mechanisms, this factor also measures the accessibility, impartiality and efficiency of the mediation and arbitration system, which help the parties resolve civil disputes. Criminal justice (factor 8) assesses the effectiveness of the criminal justice system as an important aspect of the rule of law. An effective criminal justice system is able to investigate and prosecute crimes successfully and timely, through a system that is impartial and non-discriminatory, without corruption and political influence, while ensuring that the rights of the victims and the accused are effectively protected. Creating an effective criminal justice system also requires corrective mechanisms that effectively suppress criminal behavior. Consequently, the assessment of the effectiveness of the criminal justice system should take into account the whole system, including the police, lawyers, prosecutors, judges and prison officers. In the area of accessibility of justice, unreasonable delays in court proceedings and improper political influence are highlighted as key problems.

\section{CONCLUSIONS}

According to the available data, Serbia belongs to unconsolidated democracies that are still facing the challenges of pursuing democratization and rule of law. The analysis of the rule of law indicators from different sources points to the weaknesses of the institutional and legal environment in Serbia. Serbia has advanced in the sphere of the rule of law, but the situation in this area cannot be described as satisfactory. Further reforms in the field of rule of law and legal security are necessary for further consolidation of democracy. The legal framework that defines and protects property rights in Serbia is mostly well defined. However, the main problems lie in the field of implementation. Courts are slow and inefficient, leading to lengthy court proceedings, accompanied with high costs. The low degree of efficiency of the regulatory framework is the result of the fact that the rules are not implemented effectively; there are a lot of undue delays in the application of rules and political interference.

The low level of judicial independence is considered as the weakest link in the mechanism of horizontal accountability. There is a strong external influence on the judiciary and the prosecution, mainly on the part of the executive power, which significantly affects court 
proceedings and the protection of property rights. The degree of judicial independence points to the quality of horizontal accountability, which includes the separation of powers between the mutually independent and autonomous bodies of the executive, the legislative and the judicial powers. The capacities of the legislative and judicial authorities to control the executive power are limited, while the functioning of the judiciary is hampered by political pressures, inefficiency and corruption, which undermines the system of horizontal accountability. In spite of the officially adopted legal framework for combating corruption and the abuse of power, there are very few cases of officials being prosecuted for misconduct.

The rule of law is important for the consolidation of democracy. The violation of the rule of law and horizontal accountability can destabilize other parts of the democratic system and result in a return to authoritarianism. One of the indicators of the potential danger of returning to authoritarianism is the deterioration within the factor Constraints on government powers, where a greater decline has been recorded than in any other factor within the Rule of Law Index in recent years. This factor measures the degree to which those who govern are limited by formal and nongovernmental mechanisms, such as an independent judiciary, freedom of the press, etc.

Different factors have contributed to this situation in the area of rule of law, starting from the historical heritage and social, political or cultural factors, shaping today's institutions and policies. One of the characteristics of the transition in Serbia, which significantly contributed to the weakening of the rule of law, is unfinished privatization. A significant amount of state-owned resources has strengthened the state's power to control other social and political actors. One should not neglect the fact that the transition in Serbia took place during the period marked by civil wars and international military intervention, which contributed to institutional degradation and institutional inefficiency.

Serbia also has a long history of strong informal institutions, which affects the prevalence and impact of informal networks and clientelism. These networks gave rise to the development of informal institutions that have the potential to suppress the formal ones, thus creating favorable conditions for the abuse of power by political elites and unfavourable institutional development in many areas, from the judiciary to independent regulatory bodies.

\section{REFERENCES}

Beetham, D. \& Boyle, K. (1995). Introducing Democracy. 80 Questions and Answers, Polity Press, Cambridge. Bertelsman Foundation (2018). Bertelsman Transformation Index 2018 - Serbia Country Report, https://www.btiproject.org/en/reports/country-reports/detail/itc/SRB/ (accessed 20.03.2019).

Diamond, L. (1999), Developing Democracy. Toward Consolidation, John Hopkins University Press, London.

Economist Intelligence Unit (2018), Democracy Score, https://www.eiu.com/topic/democracy-index (accessed 11.03.2019).

Elster, J. (1988). Introduction/In Elster, J., Slagstad (eds), Constitutionalism and Democracy/.-, Cambridge, Polity Press, pp.1-18.

Fraser Institute (2016). Economic Freedom 2016. https://www.fraserinstitute.org/economic-freedom/dataset?geozone= world \&page=dataset $\&$ min-year=2\&max-year $=0 \&$ filter=1\&countries=SRB/, 20.03.2019.

Freedom House (2018). Nations in Tranzit 2018 - Serbia Country Profile. https://freedomhouse.org/report/nationstransit/2018/serbia/ (accessed 25.03.2019).

Freedom House (2019). Freedom in the World 2019 - Serbia Country profile, https://freedomhouse.org/report/ freedom-world/2019/serbia/ (accessed 15.03.2019).

Hadenius, A. \& Teorell, J. (2007). Pathways from Authoritarianism, Journal of Democracy, Vol. 18, No. 1, pp. 143-157.

Heritage Foundation (2019). Index of economic freedom 2019, https://www.heritage.org/index/country/serbia/ (accessed 10.03.2019). 
Howard, M. M. \& Roessler, P. G (2006). Liberalizing Electoral Outcomes in Competitive Authoritarian Regimes, American Journal of Political Science, Vol. 50, No. 2, pp. 365-381.

Huntington, S.P. (1991). The third wave. Democratization in the Late Twentieth Century, University of Oklahoma Press, Oklahoma.

Linz, J., Stepan, A. (1996). Toward Consolidated Democracy, Journal of Democracy, Vol. 7, No. 3, pp. 14-33.

Merkel, W, Puhle, H-J; Croissant, A., Eicher, C. \& Thiery, P. (2003). Defekte Demokratie: Band 1: Theorie. Westdeutscher Verlag, Opladen.

Merkel, W. (2004). Embedded and Defective Democracies, Democratization, Vol. 11, No. 5, pp. $33-58$.

Merkel, W. (2008). Plausible Theory, Unexpected Results: The Rapid Democratic Consolidation in Central and Eastern Europe, International Politics and Society, Newsletter der Friedrich-Ebert-Stiftung 2/2008, pp. 11-29.

O’Donnell, G. (1996). Illusions about Consolidation, Journal of Democracy, Vol. 7, No. 2, pp. 34-51.

O'Donnell, G. (1998). Horizontal Accountability in New Democracies, Journal of Democracy, Vol.3, No.9, pp. $112-126$.

Прица, М. (2018). Правни принципи у поретку правне државе: канони правног поретка и „унутрашњег правног система“, Зборник радова Правног факултета у Hишу, Vol. LVII, бр. 80, pp. 135-180.

Property Rights Alliance (2018). International Property Rights Index 2018, available at https://www.internationalpropertyrightsindex.org/full-report/ 10.03.2019.

Przeworski, A. (1991). Democracy and the Market. Political and Economic Reforms in Eastern Europe and Latin America, Cambridge University Press, Cambridge.

Roessler, P.G. \& Howard, M.M. (2009). Post-Cold War Political Regimes: When Do Elections Matter?/ In Staffan I. L. (ed), Democratization by Elections: A New Mode of Transition/.- The Johns Hopkins University Press, Baltimore.

Sagay, I. (1996). The Travails of Democracy and the Rule of Law/ In Ajomo, M.A., Sambo, A. (eds), Democracy and the Rule of Law/.- Spectrum Books Ltd, Ibadan, Nigeria.

Schumpeter, J. (1942). Capitalism, Socialism and Democracy, Harper Perennial, London.

World Bank (2017). Worldwide Governance Indicators 2017. http://info.worldbank.org/governance/wgi/\#reports/ (accessed 12.03.2019).

World Justice Project (2012). Rule of Law Index 2012. https://worldjusticeproject.org/sites/default/files/documents/ WJP_Index_Report_2012.pdf (accessed 15.03.2019).

World Justice Project (2019). Rule of Law Index 2019. https://worldjusticeproject.org/our-work/research-and-data/wjprule-law-index-2019/ (accessed 12.03.2019).

\section{VLADAVINA PRAVA I KONSOLIDACIJA DEMOKRATIJE U SRBIJI}

Poznate međunarodne organizacije klasifikuju Srbiju kao demokratiju. Međutim, one ocenjuju stanje demokratije prema teorijskom konceptu izborne demokratije, što može da stvori zabludu da slobodni izbori predstavljaju ne samo neophodan, već i dovoljan uslov za demokratiju. Koncept liberalne konsolidovane demokratije, pored proceduralnih aspekata, podrazumeva ispunjavanje strožih normativnih $i$ analitičkih kriterijuma, kao što su vladavina prava i mehanizmi vertikalne $i$ horizontalne odgovornosti, koji predstavljaju institucionalne garancije za primenu osnovnih demokratskih principa. $U$ nedostatku ovih mehanizama, izborne demokratije postaju manjkave. Prema relevantnim istraživanjima, Srbija je klasifikovana kao polukonsolidovana (defektna ili manjkava demokratija). Nepravilnosti u izbornim procedurama, kao $i$ kršenje elemenata koji garantuju poštovanje demokratskih normi $i$ institucija posljednjih godina, ukazuju na određeno demokratsko nazadovanje. Imajući ovo na umu, u radu se istražuje u kojoj meri vladavina prava predstavlja podršku konsolidaciji demokratije u Srbiji $i$ ukazuje na potencijalne uzroke nedostataka u ovoj oblasti, koji otežavaju konsolidaciju demokratije.

Ključne reči: demokratija, konsolidacija, vladavina prava, Srbija 